\title{
More welcome data on pulmonary hypertension in South Africa
}

This issue of the AJTCCM contains more welcome data on the problem of pulmonary hypertension (PH) in South Africa (SA). The paper in this issue by Dahim et al.$^{[1]}$ describes the experience of the Pulmonary Hypertension Clinic at Inkosi Albert Luthuli Central Hospital and makes interesting comparisons with the data from Groote Schuur Hospital published in 2018. ${ }^{[2]}$ Retrospective data on 91 patients over an 8 -year period are presented. This cohort excluded patients with type $2 \mathrm{PH}$, who were managed by cardiologists.

The trends are similar to those seen in Cape Town, with HIVassociated $\mathrm{PH}$, idiopathic pulmonary arterial hypertension and chronic thromboembolic $\mathrm{PH}(\mathrm{CTEPH})$ being the most common causes seen. The fact that more than $30 \%$ of the patients had HIVassociated $\mathrm{PH}$ probably reflects the prevalence of disease and referral pattern in the area, although a high prevalence compared with the rest of the world was also reported for Cape Town. This was commented upon by Goolam Mahomed ${ }^{[3]}$ in a previous editorial.

The investigation of this group included echocardiography in all, although right-heart catheterisation was not performed in any patients. Monotherapy with sildenafil was used in $66 \%$, with some evidence of a drop in pulmonary artery systolic pressure and functional improvement.

Twelve patients (13\%) had CTEPH compared with the $38 \%$ seen in Cape Town. It seems that no specific therapy could be offered to these patients although international guidelines suggest that pulmonary endarterectomy be offered to eligible patients as this is associated with a significant survival advantage..$^{[4]}$ Targeted medical therapy with riociguat and balloon pulmonary angioplasty have been suggested for those not suitable for pulmonary endarterectomy surgery.
Investigation and management of $\mathrm{PH}$ remains a major challenge in SA, particularly in the public sector, where access to right-heart catheterisation, reactivity testing and a variety of agents for treatment remains very limited, despite the large body of evidence and recommendations for these interventions. ${ }^{[5,6]}$

Richard Raine, MB ChB, MMed (Med), FCP (SA)

Respiratory Clinic, Department of Medicine, Faculty of Health Sciences, University of Cape Town, South Africa

Richard.Raine@uct.ac.za

Afr J Thoracic Crit Care Med 2021;27(1):3. https://doi.org/10.7196/ AJTCCM.2021.v27i1.142

1. Dahim M, Mitha M, Connolly C, Nyamande K. Pulmonary hypertension in Durban: Spectrum of disease, clinical presentation and treatment outcomes at the main respiratory pulmonary hypertension clinic in KwaZulu-Natal. Afr J Thoracic Crit Care Med 2021;27(1):6-9. https://doi.org/10.7196/AJTCCM.2021.v27i1.118

2. Davies-van Es S, Calligaro G, Manning K, et al. The aetiology, clinical presentation and treatment of patients with pulmonary hypertension in Cape Town: A preliminary report from the Groote Schuur Hospital Pulmonary Hypertension Registry. Afr J Thoracic Crit Care Med 2018;24(4):133-138. https://doi.org/10.7196/AJTCCM.2018. v24i4.218

3. Goolam Mahomed A. Pulmonary hypertension in South Africa - at last some original research! Afr J Thoracic Crit Care Med 2018;24(4):126. https://doi.org/10.7196/ AJTCCM.2018.v24i4.233

4. Kim NH, Delcroix M, Jais X, et al. Chronic thromboembolic pulmonary hypertension. Eur Respir J 2019;53(1):1801915. https://doi.org/10.1183/13993003.01915-2018

5. Essop MR, Galie N, Badesch DB, et al. Management of pulmonary hypertension. S Afr Med J 2015;105(6):437-439.

6. Galiè N, Humbert M, Vachiery J-L, et al. 2015 ESC/ERS Guidelines for the diagnosis and treatment of pulmonary hypertension. Eur Respir J 2015;46(4):903. https://doi. org/10.1183/13993003.01032-2015 